\title{
Description of Gluconacetobacter sacchari sp. nov., a new species of acetic acid bacterium isolated from the leaf sheath of sugar cane and from the pink sugar-cane mealy bug
}

\author{
Ingrid H. Franke, ${ }^{1}$ Mark Fegan, ${ }^{2}$ Chris Hayward, ${ }^{1}$ Graham Leonard, ${ }^{3}$ \\ Erko Stackebrandt ${ }^{4}$ and Lindsay I. Sly ${ }^{1}$
}

Author for correspondence: Lindsay I. Sly. Tel: +61 73365 2396. Fax: +61 733654620.
e-mail: sly@ biosci.uq.edu.au

\footnotetext{
1 Centre for Bacterial Diversity and Identification, Department of Microbiology, The University of Queensland, Brisbane, Australia

2 Cooperative Research Centre for Tropical Plant Pathology, The University of Queensland, Brisbane, Australia

3 Bureau of Sugar Experiment Stations, Indooroopilly, Brisbane, Australia

4 DSMZ-Deutsche Sammlung von Mikroorganismen und Zellkulturen,

Braunschweig, Germany
}

\begin{abstract}
A new species of the genus Gluconacetobacter, for which the name Gluconacetobacter sacchari sp. nov. is proposed, was isolated from the leaf sheath of sugar cane and from the pink sugar-cane mealy bug, Saccharicoccus sacchari, found on sugar cane growing in Queensland and northern New South Wales, Australia. The nearest phylogenetic relatives in the $\alpha$-subclass of the Proteobacteria are Gluconacetobacter liquefaciens and Gluconacetobacter diazotrophicus, which have 98.8-99.3\% and 97.9-98.5\% 16S rDNA sequence similarity, respectively, to members of Gluconacetobacter sacchari. On the basis of the phylogenetic positioning of the strains, DNA reassociation studies, phenotypic tests and the presence of the Q10 ubiquinone, this new species was assigned to the genus Gluconacetobacter. No single phenotypic characteristic is unique to the species, but the species can be differentiated phenotypically from closely related members of the acetic acid bacteria by growth in the presence of $0.01 \%$ malachite green, growth on $30 \%$ glucose, an inability to fix nitrogen and an inability to grow with the L-amino acids asparagine, glycine, glutamine, threonine and tryptophan when D-mannitol was supplied as the sole carbon and energy source. The type strain of this species is strain SRI 1794' (= DSM 12717').
\end{abstract}

Keywords: Gluconacetobacter sacchari, taxonomy, phylogeny, acetic acid bacteria, pink sugar-cane mealy bug

\section{INTRODUCTION}

The acetic acid bacteria are Gram-negative, obligately aerobic, rod-shaped bacteria, the habitats and biology of which are relatively well-known, due to the considerable economic impact the bacteria have on industry (Swings, 1992). An extensive literature about these organisms has accumulated since the first description of acetic acid bacteria by Persoon (1822). Relationships among the acetic acid bacteria were first

The GenBank accession numbers for the 16S rRNA gene sequences of the strains reported in this study are: SRI 244, AF127391; SRI 1990, AF127392; SRI 1957, AF127393; SRI 1939, AF127394; SRI 1994, AF127395; SRI 1995, AF127396; SRI 1212, AF127397; SRI 1214, AF127398; SRI 1321, AF127399; SRI 1941, AF127400; SRI 1206, AF127401; SRI 1205, AF127402; IFR 101, AF127403; SRI 1951, AF127404; SRI 1230, AF127405; SRI 1216, AF127406; SRI 1794', AF127407; SRI 1853, AF127408; SRI 1255, AF127409; SRI 1953, AF127410; IF 9701, AF127411; IF 2-6, AF127412; and IF 9645, AF127413. studied genotypically by DNA-rRNA hybridization (Gillis \& De Ley, 1980) and then by DNA-DNA hybridization (Yamada \& Kondo, 1984; Entani et al., 1985; Micales et al., 1985; Urakami et al., 1989; Sievers et al., 1992). The first sequencing of rRNA genes was conducted on the $5 \mathrm{~S}$ rRNA gene (Bulygina et al., 1992) and, subsequently, a paper on the phylogenetic positioning of species of the genera Acetobacter, Gluconobacter and Acidomonas among acidophilic bacteria in the $\alpha$-subclass of the Proteobacteria, based on comparative 16S rRNA gene sequence analysis, was published (Sievers et al., 1994a). There have been several publications on the taxonomy of the acetic acid bacteria (Yamada \& Kondo, 1984; Sievers et al., 1994b; Yamada et al., 1997). In 1984, Yamada \& Kondo divided the members of Acetobacter at the subgeneric level on the basis of differences in their ubiquinone systems and introduced the new 
subgenus Gluconoacetobacter (ex Asai) Yamada and Kondo, with the type species Gluconoacetobacter liquefaciens, for organisms equipped with the Q10 ubiquinone. The Q9-equipped species were, meanwhile, accommodated in the subgenus Acetobacter of the genus Acetobacter. Recently, Yamada et al. (1997) proposed the elevation of the subgenus Gluconoacetobacter to the generic level, on the basis of partial base sequences of the $16 \mathrm{~S}$ rRNA gene. The species containing the Q9 ubiquinone remain in the genus Acetobacter. The name Gluconoacetobacter was orthographically incorrect and has recently been corrected to Gluconacetobacter (Yamada et al., 1998), in accordance with Rule 61 of the International Code of Nomenclature of Bacteria. The corrected name will be used throughout this paper.

This paper describes the finding of a new species of Gluconacetobacter, isolated from the leaf sheath of sugar cane and from the pink sugar-cane mealy bug, found in the leaf sheath of various sugar cane varieties growing in Queensland, Australia. The pink sugarcane mealy bug, Saccharicoccus sacchari (Cockerell) (Homiptera: Pseudococcidae), is common to all sugarcane-growing countries and is almost the exclusive species of mealy bug on commercially grown cane (Inkerman et al., 1986). Our research was conducted to extend the work of Ashbolt \& Inkerman (1990), who found that the pink sugar-cane mealy bug supports the growth of populations of bacteria appearing to resemble members of the Acetobacteraceae. Several strains were studied by Gillis et al. (1989) and identified as Acetobacter diazotrophicus. However, as we have been unable to detect nitrogen fixation in some mealybug isolates, we have undertaken studies to clarify the taxonomic position of these bacteria.

On the basis of 16S rRNA gene sequence information, phenotypic characteristics, fatty acid composition, DNA-DNA hybridization and past research, we conclude that the organisms isolated from the leaf sheath of sugar cane and from the pink sugar-cane mealy bug constitute a new species in the genus Gluconacetobacter, for which we propose the name Gluconacetobacter sacchari sp. nov.

\section{METHODS}

Bacterial strains and cultivation. The strains included in this study and their sources are listed in Table 1. These strains were grown and maintained on either glucose/yeast extract/ calcium carbonate (GYC) agar (De Ley et al., 1984), which consisted of $50 \mathrm{~g}$ glucose, $10 \mathrm{~g}$ yeast extract, $30 \mathrm{~g}$ calcium carbonate and $25 \mathrm{~g}$ agar $1^{-1}$ distilled water, or on WL nutrient agar (Oxoid), which contained 4 g yeast extract, $4 \mathrm{~g}$ tryptone, $50 \mathrm{~g}$ glucose, $0.55 \mathrm{~g} \mathrm{~K}_{2} \mathrm{HPO}_{4}, 0.425 \mathrm{~g} \mathrm{KCl}, 0.125 \mathrm{~g}$ $\mathrm{CaCl}_{2}, 0.125 \mathrm{~g} \mathrm{MgSO}_{4}, 0.0025 \mathrm{~g} \mathrm{FeCl}_{3}, 0.0025 \mathrm{~g} \mathrm{MnSO}_{4}$,

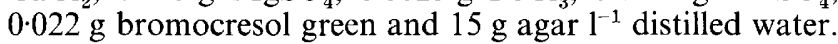
Cultivation was at $28^{\circ} \mathrm{C}$ for $3-4 \mathrm{~d}$.

Isolation of strains from mealy bugs. New bacterial strains to supplement an existing collection at the Sugar Research Institute, Mackay, Queensland, Australia (Table 1), were isolated from the pink sugar-cane mealy bug (Saccharicoccus sacchari) found in the leaf sheath pocket of sugar cane from different sites throughout Queensland, Australia, over the period 1995-1997. Mealy bugs were placed in $1.5 \mathrm{ml} 0.05 \%$ peptone water $(\mathrm{pH} 3)$ and homogenized using a sterile swab stick and vortexing. Serial dilutions of the homogenized suspension were made and samples were spread on WL nutrient agar plates adjusted to $\mathrm{pH} 3$, which contained $100 \mathrm{mg}$ cycloheximide $\mathrm{1}^{-1}$ to inhibit fungal contamination. Colonies resembling Gluconacetobacter were selected from the isolation plates and isolated in pure culture.

Phenotypic characterization. GYC and WL nutrient agar plates were used for the pre-culture of bacterial strains, and cultures were incubated for $3-4 \mathrm{~d}$ at $28^{\circ} \mathrm{C}$ prior to test inoculations. The formation of water-soluble brown pigments on GYC agar plates and the formation of hydrogen sulfide from L-cysteine were determined by the method of Swings et al. (1992). Bacterial motility was tested by growth through a Craigie tube in semi-solid medium $(0.3 \% \mathrm{WL}$ nutrient agar) and confirmed microscopically by motility in a hanging-drop preparation. Flagellar morphology was determined by transmission electron microscopy after negative staining for $30 \mathrm{~s}$ with $1 \%$ ammonium molybdate containing $0.003 \%$ bacitracin. The Gram stain reaction was conducted using the method of Skerman (1967), modified by the addition of $5 \%$ polyvinylpyrrolidone to the iodine reagent (bioMérieux). The oxidase test was performed using $1 \%(\mathrm{w} / \mathrm{v}) N, N, N^{\prime}, N^{\prime}$-tetramethyl 1,4-phenylenediamine hydrochloride (Kovacs, 1956) and confirmed using oxidase identification sticks (Oxoid). Catalase activity was detected by the production of $\mathrm{O}_{2}$ from $3 \% \mathrm{H}_{2} \mathrm{O}_{2}$. Glycerol ketogenesis was observed using the method and medium of Carr (1968). Nitrate reduction was tested from nitrate peptone water ( $10 \mathrm{~g}$ peptone, $2 \mathrm{~g} \mathrm{KNO}_{3} \mathrm{~K}^{-1}$ distilled water; $\mathrm{pH} 7$ ), using the method of Skerman (1967). The production of acid from sorbitol, D-mannitol and propanol was tested according to the method of Asai et al. (1964). Oxidation of ethanol was tested using the medium of Frateur (1950) and acetate and lactate oxidation were tested using the medium of Asai et al. (1964). Growth in the presence of $0.01 \%$ malachite green was tested using the medium of Gosselé et al. (1983). The medium of Entani et al. (1985) was used to test for the ability of strains to grow in $6 \%$ ethanol. Growth in $30 \%$ glucose was tested according to a modified method of De Ley et al. (1984), in which the medium contained $0.3 \%$ peptone, $0.5 \%$ yeast extract and $30 \%$ glucose. The use of the L-amino acids asparagine, glycine, glutamine, threonine and tryptophan as sole nitrogen sources for growth was tested using the medium of Swings et al. (1992). Growth with carbon sources was tested in Hoyer's medium lacking mannitol (De Ley et al., 1984), with filter-sterilized carbon sources included at final concentrations of $0.1 \%$. The production of 2-ketogluconic, 5-ketogluconic and 2,5diketogluconic acids was tested by detection using HPLC, following growth in a medium containing $0.3 \%$ yeast extract and $3 \%$ glucose at $28^{\circ} \mathrm{C}$ for $1-7 \mathrm{~d}$ (Blake et al., 1984).

The acetylene reduction assay was tested on bacteria grown on the semi-solid, nitrogen-poor medium LGI-P (Cavalcante \& Döbereiner, 1988), using $10 \%(\mathrm{v} / \mathrm{v})$ acetylene, according to the method of Li \& Macrae (1991).

The numerical analysis program NTSYS-pc version 1.6 (Applied Biostatistics) was used to analyse the phenotypic characteristics (Dice coefficient) and phenograms were constructed using the unweighted pair-group method with averages (UPGMA). 
Table 1. Bacterial strains used in this study

Abbreviations: ACM, Australian Collection of Microorganisms, Department of Microbiology, The University of Queensland, St Lucia, Australia; DSMZ, Deutsche Sammlung von Mikroorganismen und Zellkulturen, Braunschweig, Germany; IF, Ingrid Franke; LMG, Culture Collection Laboratorium voor Microbiologie, University of Ghent, Belgium; SRI, Sugar Research Institute, Mackay, Australia.

\begin{tabular}{|c|c|c|}
\hline Species & Strain & Source \\
\hline \multirow[t]{2}{*}{ Acetobacter aceti } & ACM 17 & $\mathrm{ACM}$ \\
\hline & SRI 1321 & Mealy bug, Queensland, SRI \\
\hline Acetobacter pasteurianus & ACM 2866 & $\mathrm{ACM}$ \\
\hline \multirow{5}{*}{$\begin{array}{l}\text { Gluconacetobacter } \\
\text { diazotrophicus }\end{array}$} & LMG $7603^{\mathrm{T}}$ & LMG \\
\hline & SRI 1205 & Mealy bug, Queensland, SRI \\
\hline & SRI 1206 & Mealy bug, Queensland, SRI \\
\hline & SRI 1212 & Mealy bug, Queensland, SRI \\
\hline & SRI 1990 & Mealy bug, Hawaii, SRI \\
\hline \multirow[t]{4}{*}{ Gluconacetobacter liquefaciens } & LMG $1381^{\mathrm{T}}$ & LMG \\
\hline & SRI 244 & Sugar cane, Queensland, SRI \\
\hline & SRI 1957 & $\begin{array}{l}\text { Non-Saccharicoccus sacchari mealy } \\
\text { bug, marble-diseased pineapple, The } \\
\text { Philippines, SRI }\end{array}$ \\
\hline & SRI 1994 & Mealy bug, Hawaii, SRI \\
\hline Gluconacetobacter hansenii & DSM $5602^{\mathrm{T}}$ & DSMZ \\
\hline Gluconacetobacter xylinus & ACM 19 & $\mathrm{ACM}$ \\
\hline \multirow{13}{*}{ Novel mealy-bug taxon } & SRI 1216 & Sugar cane, Queensland, SRI \\
\hline & SRI 1230 & Sugar cane, Queensland, SRI \\
\hline & SRI 1255 & Sugar cane, Queensland, SRI \\
\hline & SRI $1794^{\mathrm{T}}$ & Sugar cane, Queensland, SRI \\
\hline & SRI 1801 & Sugar cane, Queensland, SRI \\
\hline & SRI 1853 & Mealy bug, Queensland, SRI \\
\hline & SRI 1908 & Mealy bug, Queensland, SRI \\
\hline & SRI 1951 & Mealy bug, Queensland, SRI \\
\hline & SRI 1953 & Mealy bug, New South Wales, SRI \\
\hline & IF $2-6$ & Mealy bug, Queensland, this study \\
\hline & IF 9645 & Mealy bug, Queensland, this study \\
\hline & IF 9700 & Mealy bug, Queensland, this study \\
\hline & IF 9701 & Mealy bug, Queensland, this study \\
\hline \multirow[t]{7}{*}{ Unidentified bacteria } & SRI 1214 & Mealy bug, Queensland, SRI \\
\hline & SRI 1313 & Mealy bug, Queensland, SRI \\
\hline & SRI 1793 & Sugar cane, Queensland, SRI \\
\hline & SRI 1939 & Mealy bug, Queensland, SRI \\
\hline & SRI 1941 & Mealy bug, Queensland, SRI \\
\hline & SRI 1995 & Mealy bug, Hawaii, T. Taniguchi \\
\hline & [Acetobacter] IFR 101 & Vinegar acidifier, IFR, Norwich, UK \\
\hline
\end{tabular}

Determination of ubiquinones. Ubiquinones were analysed according to the procedure of Hippe et al. (1997), with modifications. Freeze-dried bacterial cells were extracted twice with chloroform/methanol $(2: 1 \mathrm{v} / \mathrm{v})$. Combined extracts were dried using a Turbo Vap Evaporator (Zymark), operated at $40^{\circ} \mathrm{C}$ with nitrogen gas sparging. The extracts were resuspended in a chloroform/water/methanol solution $(2: 2: 1)$ and centrifuged to separate polysaccharides from the quinones. The chloroform phase was transferred to a clean tube, the chloroform was evaporated and the resulting quinone preparation was dissolved in acetone.
Ubiquinones were separated by TLC using silica gel $60 \mathrm{~F}_{254^{-}}$ coated plastic plates (Merck). The running phase employed was petroleumbenzene/diethyl ether $(85: 15)$ and the dried plate was examined under UV light for quinones, which were cut from the plate and eluted with diethyl ether. The solvent was evaporated and quinones were resuspended in 2propanol and then filtered through a $0.2 \mu \mathrm{m}$ Dyna Gard hollow-fibre syringe. Purified quinones were examined by HPLC and separated on a reverse-phase column (Ecocart 125-3 silica gel column with RP-18, end-capped) maintained at $40{ }^{\circ} \mathrm{C}$. The eluent was acetonitrile/2-propanol $(65: 35 \mathrm{v} / \mathrm{v})$ 


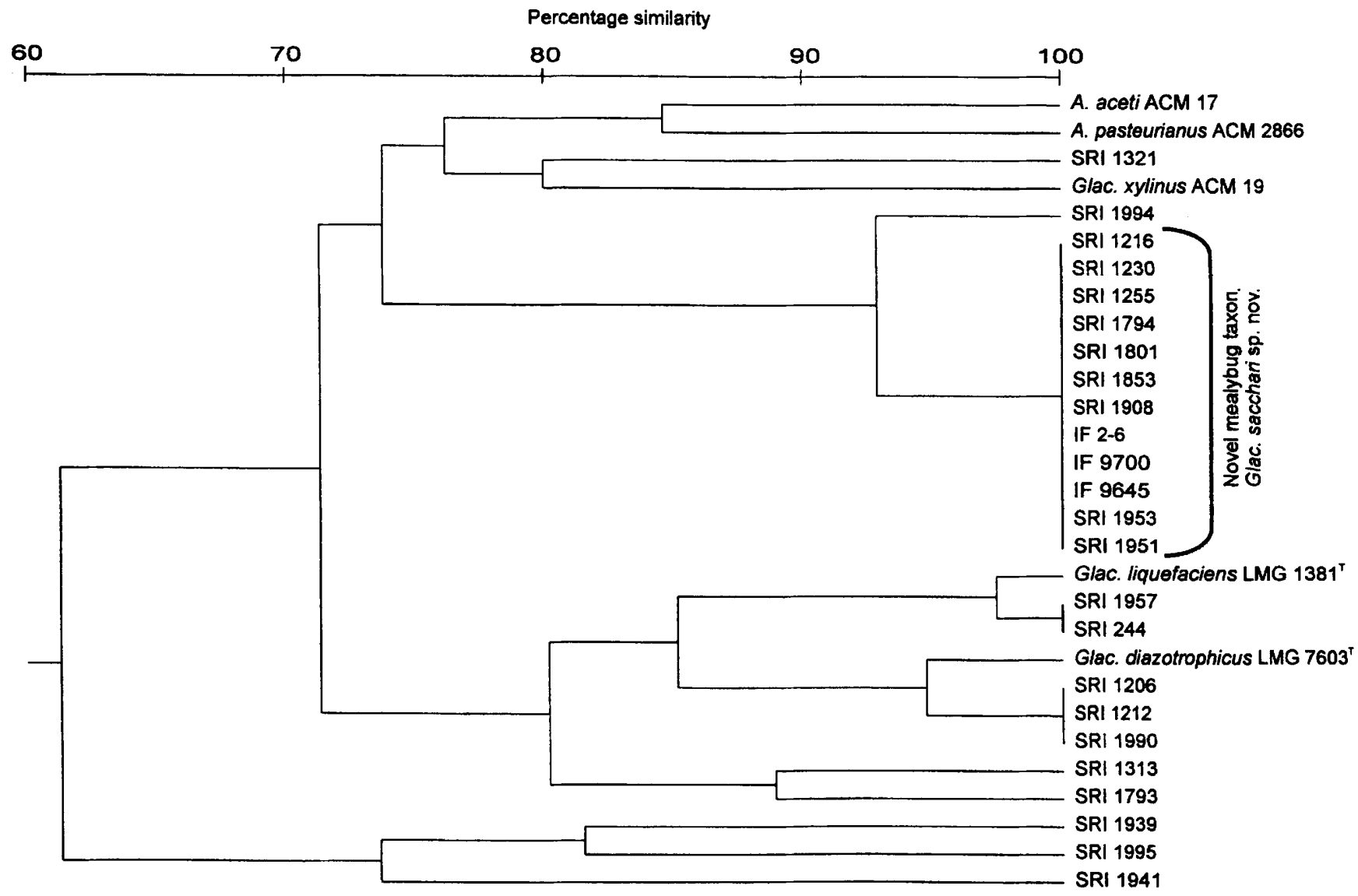

Fig. 1. Dendrogram showing the relationship of isolates determined by a numerical analysis of their phenotypic characteristics. Glac., Gluconacetobacter.

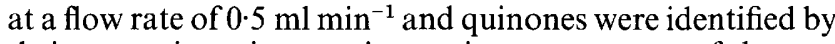
their retention times using quinone extracts of known composition as standards.

Fatty acid composition. Cellular fatty acids from bacterial strains were identified using the Microbial Identification system MIDI (Hewlett Packard). Bacteria were grown on GYC plates containing $10 \%$ glucose for $48 \mathrm{~h}$ and the instructions of the manufacturer were followed exactly for fatty acid extraction and analysis.

16S rRNA gene sequencing. DNA was extracted from bacterial strains suspended in a $0 \cdot 15 \mathrm{M} \mathrm{NaCl} / 0 \cdot 1 \mathrm{M}$ EDTA buffer and cell lysis was induced by the addition of $5 \mu \mathrm{l}$ lysozyme $\left(0.3 \mu \mathrm{g} \mu \mathrm{l}^{-1}\right)$ and incubation at $37^{\circ} \mathrm{C}$ for $20 \mathrm{~min}$. Proteinase $\mathrm{K}(15 \mu \mathrm{l}$ of a $1 \%$ solution in distilled water $)$ and SDS $(10 \mu \mathrm{l}$ of a $10 \%$ solution) were added and the preparation was incubated at $60{ }^{\circ} \mathrm{C}$ for $30 \mathrm{~min}$. Nucleic acids were purified by extraction with an equal volume of phenol (water-saturated) and subsequently by extraction with an equal volume of chloroform. An aliquot of the aqueous phase was used directly in PCR. The 16S rRNA gene was amplified in a $100 \mu \mathrm{l}$ reaction mixture containing $1 \times$ buffer $\left[67 \mathrm{mM}\right.$ Tris $/ \mathrm{HCl}(\mathrm{pH} 8.5), 16.6 \mathrm{mM}\left(\mathrm{NH}_{4}\right)_{2} \mathrm{SO}_{4}$, $0.45 \%(\mathrm{v} / \mathrm{v})$ Triton $\mathrm{X}-100,200 \mu \mathrm{g}$ gelatin $\mathrm{ml}^{-1}$ ], $1.5 \mathrm{mM}$ $\mathrm{MgCl}_{2}, 200 \mu \mathrm{M}$ dNTPs, $0.25 \mu \mathrm{M}$ of each of the primers $27 \mathrm{f}$ and $1525 \mathrm{r}$ (Lane, 1991) and 1 U of Tth plus DNA polymerase (Biotech Australia). Reactions were overlaid with mineral oil to prevent evaporation. A Perkin-Elmer Cetus model 480 thermal cycler was programmed for PCR amplifications and the program was started with a 3 min $96^{\circ} \mathrm{C}$ denaturation step, followed by the addition of $T t h$ plus polymerase at $72^{\circ} \mathrm{C}$. The thermal profile consisted of 28 cycles of $94^{\circ} \mathrm{C}$ for $1 \mathrm{~min}, 72^{\circ} \mathrm{C}$ for $2 \mathrm{~min}$ and $48^{\circ} \mathrm{C}$ for $1 \mathrm{~min}$, followed by an extension phase of $48^{\circ} \mathrm{C}$ for $1 \mathrm{~min}$ and $72^{\circ} \mathrm{C}$ for $5 \mathrm{~min}$. Amplification products were electrophoresed at $5 \mathrm{~V} \mathrm{~cm}^{-1}$ for $30 \mathrm{~min}$ on a $1 \%$ agarose gel and visualized by ethidiumbromide staining under UV light.

Purified PCR products were sequenced directly using the Taq Dye Terminator cycle sequencing kit (Applied Biosystems) according to the instructions of the manufacturer. The sequencing primers 27f, 319r, 357f, 519r, 530f, 907r, 926f, 1100r, 1114f, 1525r, 1492r (Lane, 1991) and 803f (Stackebrandt \& Charfreitag, 1990) were used. Extension products were purified using a phenol/chloroform extraction method (ABI) and sequences were determined with an Applied Biosystems model 373A sequencer.

The 16S rRNA gene sequences determined were manually aligned with each other and with other reference $16 \mathrm{~S}$ rRNA gene sequences using the ae 2 sequence editor (Maidak et al., 1997). All ambiguous sites were removed from the alignment prior to phylogeny inference. Evolutionary distances between pairs of DNA sequences were determined using the algorithm of Jukes \& Cantor (1969) in the DNADIST program 
Description of Gluconacetobacter sacchari sp. nov.

Table 2. Salient characteristics that differentiate the novel mealy-bug isolates from closely related species of Gluconacetobacter and Acetobacter

\begin{tabular}{|c|c|c|c|c|c|c|c|c|}
\hline Characteristic & $\begin{array}{l}\text { Novel mealy- } \\
\text { bug isolates }\end{array}$ & $\begin{array}{l}\text { G. diazotrophicus } \\
\text { LMG } 7603^{\mathrm{T}}\end{array}$ & $\begin{array}{l}\text { G. Liquefaciens } \\
\text { LMG } 1381^{\top}\end{array}$ & G. europaeus* & G. hanseniï* & $\begin{array}{l}\text { G. xylinus } \\
\text { ACM } 19\end{array}$ & $\begin{array}{r}\text { A. aceti } \\
\text { ACM } 17\end{array}$ & $\begin{array}{l}\text { A. pasteurianus } \\
\text { ACM } 2866\end{array}$ \\
\hline $\begin{array}{l}\text { Formation of water-soluble brown pigment on } \\
\text { GYC plate }\end{array}$ & + & + & + & $\mathrm{NA}$ & - & - & - & - \\
\hline Acetylene reduction & - & + & - & $\mathrm{NA}$ & - & - & - & - \\
\hline Glycerol ketogenesis & - & - & + & NA & + & - & + & - \\
\hline Formation of acid from glucose & + & + & + & NA & + & + & + & + \\
\hline \multicolumn{9}{|l|}{ Formation from D-glucose of: } \\
\hline 2-Ketogluconic acid & + & + & + & $\mathrm{d}$ & $\mathrm{d}$ & + & + & + \\
\hline 5-Ketogluconic acid & + & + & + & d & $\mathrm{d}$ & + & + & + \\
\hline 2,5-Diketogluconic acid & + & + & + & $\mathrm{NA}$ & - & - & - & - \\
\hline Oxidation of ethanol & + & + & + & + & + & + & + & + \\
\hline \multicolumn{9}{|l|}{ Acid production from: } \\
\hline D-Mannitol & - & - & - & $\mathrm{NA}$ & - & - & - & - \\
\hline Sorbitol & - & - & - & - & $\mathrm{d}$ & - & - & - \\
\hline 1-Propanol & + & + & + & $\mathrm{NA}$ & + & + & + & + \\
\hline \multicolumn{9}{|l|}{ Growth on the following carbon sources: } \\
\hline Ethanol & + & + & + & + & - & - & + & + \\
\hline Methanol & - & - & - & - & - & - & - & - \\
\hline Dulcitol & - & - & - & $\mathrm{NA}$ & $\mathrm{d}$ & - & - & - \\
\hline Sodium acetate & + & + & + & $\mathrm{NA}$ & - & - & + & + \\
\hline Nitrate reduction & - & - & - & $\mathrm{NA}$ & $\mathrm{d}$ & - & + & - \\
\hline Growth in $6 \%$ ethanol & - & - & - & + & - & - & + & + \\
\hline Growth on $30 \%$ glucose & + & + & - & - & - & - & - & - \\
\hline Motility & + & + & + & $\mathrm{NA}$ & - & + & + & + \\
\hline Gram stain & - & - & - & $\mathrm{NA}$ & - & - & - & - \\
\hline Oxidase reaction & - & - & - & $\mathrm{Na}$ & - & - & - & - \\
\hline Catalase reaction & + & + & + & $\mathrm{NA}$ & + & - & + & + \\
\hline Sodium acetate oxidation & + & + & + & $\mathrm{NA}$ & + & + & + & + \\
\hline Sodium lactate oxidation & + & + & + & $\mathrm{NA}$ & + & + & + & + \\
\hline Formation of $\mathrm{H}_{2} \mathrm{~S}$ & - & - & - & $\mathrm{NA}$ & - & - & - & - \\
\hline \multicolumn{9}{|l|}{$\begin{array}{l}\text { Growth on the following in the presence of } \\
\text { D-mannitol as a carbon source: }\end{array}$} \\
\hline L-Asparagine & - & + & + & $\mathrm{NA}$ & + & - & - & - \\
\hline L-Glycine & - & + & + & NA & $d$ & - & - & - \\
\hline L-Glutamine & - & + & + & $\mathrm{NA}$ & + & - & + & - \\
\hline L-Threonine & - & - & + & $\mathrm{NA}$ & - & - & - & - \\
\hline L-Tryptophan & - & + & + & $\mathrm{NA}$ & - & - & - & - \\
\hline Growth on glutamate agar & + & + & + & $\mathrm{NA}$ & $\mathrm{NA}$ & - & + & - \\
\hline Growth on mannitol agar & + & + & + & $\mathrm{NA}$ & $\mathrm{d}$ & + & + & + \\
\hline Growth on $0.01 \%$ malachite-green agar & + & - & + & $\mathrm{NA}$ & $\mathrm{NA}$ & - & - & - \\
\hline $\mathrm{G}+\mathrm{C}$ content of DNA $(\mathrm{mol} \%)$ & $62-67$ & $61-63$ & $62-65$ & $56-58$ & $58-63$ & $55-63$ & $56-60$ & $53-63$ \\
\hline Ubiquinone type & Q10 & Q10 & Q10 & Q10 & Q10 & Q10 & Q9 & Q9 \\
\hline
\end{tabular}

+, Positive; -, negative; d, some strains positive; NA, result not available.

* Data from De Ley et al. (1984), Uhlig et al. (1986), Gillis et al. (1989), Sievers \& Teuber (1995), Yamada et al. (1997) and Sokollek et al. (1998).

of the PHYLIP phylogenetic analysis software package (Felsenstein, 1993). Phylogenetic trees were constructed from evolutionary distances using the neighbour-joining method of Saitou \& Nei (1987). Trees based on maximum parsimony were constructed using the DNAPARS program of PHYLIP (Felsenstein, 1993). Bootstrapping analysis using the program SEQBOOT (in PHYLIP) was undertaken to test the statistical reliability of the topology of the distance- and parsimony-generated trees using 100 bootstrap resamplings of the data.

The following 16S rRNA gene sequences were obtained from GenBank for use in the phylogenetic analyses: Acetobacter aceti JCM 7641, D30768; '[Acetobacter] intermedius' DSM 11804 ${ }^{\mathrm{T}}, \mathrm{Y} 14694 ;\left[\right.$ Acetobacter] oboediens DSM 11826 ${ }^{\mathrm{T}}$, AJ001631; Acetobacter pasteurianus LMG 1262 ${ }^{\mathrm{T}}$, X71863; Acetobacter pomorum DSM 11825 , AJ001632; Acidomonas methanolica LMG 1668 ${ }^{\mathrm{T}}$, X77468; Gluconacetobacter diazotrophicus DSM 7603 ${ }^{\mathrm{T}}$, X75618; Gluconacetobacter europaeus DSM $6160^{\mathrm{T}}$, Z21936; Gluconacetobacter hansenii LMG
$1527^{\mathrm{T}}$, X75620; Gluconacetobacter liquefaciens LMG 1382 ${ }^{\mathrm{T}}$, X75617; Gluconacetobacter xylinus LMG 1515, X75619; Gluconobacter asaii LMG 1390 ${ }^{\mathrm{T}}$, X80165; Gluconobacter cerinus LMG 1368 ${ }^{\mathrm{T}}$, X80775; Gluconobacter frateurii $\mathrm{LMG}$ $1365^{\mathrm{T}}$, X82290; Gluconobacter oxydans DSM $3503^{\mathrm{T}}$, X73820; and Rhodopila globiformis DSM 161 ${ }^{\mathrm{T}}$, D86513.

DNA isolation and characterization. Genomic DNA for DNA-DNA hybridization studies and for $\mathrm{G}+\mathrm{C}$ content determination was isolated by chromatography on hydroxyapatite, using the method of Cashion et al. (1977). DNA was dialysed against $2 \times$ SSC and DNA quality and quantity was determined spectroscopically using a microprocessor-controlled Gilford 2600 spectrophotometer. HPLC was used to determine the $\mathrm{G}+\mathrm{C}$ content, according to the method of Mesbah et al. (1989).

DNA-DNA hybridizations were conducted using the method of De Ley et al. (1970), as modified by Huss et al. (1983) and Escara \& Hutton (1980). A thermal-denaturation 
profile was determined using the Gilford 2600 spectrophotometer, equipped with a thermoelement, including four cuvettes with integrated temperature control, a thermoprogrammer (2527-R) and an automatic cuvette changer. The midpoint of the thermal denaturation curve $\left(T_{\mathrm{m}}\right)$ was determined graphically by the computer and the optimal temperature of renaturation $\left(T_{\text {or }}\right)$ was determined using the equation: $T_{\mathrm{or}}=0 \cdot 5 T_{\mathrm{m}}+65 \cdot 2-25$ (Escara \& Hutton, 1980; Huss et al., 1983). Renaturation was monitored by following $A_{260}$ and involved the denaturation of DNA $\left(50 \mu \mathrm{g} \mathrm{ml}^{-1}\right)$ at $99^{\circ} \mathrm{C}$ before renaturation at the $T_{\text {or }}, 64^{\circ} \mathrm{C}$. Levels of DNA-DNA relatedness were determined by recording absorbances every $15 \mathrm{~s}$ for $30 \mathrm{~min}$ and using the formula of De Ley et al. (1970), with the computer program TRANSFER.BAS of Jahnke (1992), where the percentage of DNA homology is determined as $100 \times\left(4 V_{\mathrm{M}}-V_{\mathrm{A}}+V_{\mathrm{B}}\right) /$ $\left[2 \times \sqrt{ }\left(V_{\mathrm{A}} \times V_{\mathrm{B}}\right)\right]$. In this formula, $V$ is the renaturation rate, $\mathrm{A}$ is DNA from strain A, B is DNA from strain B and $M$ is a mixture of equal amounts of DNA from strains $\mathrm{A}$ and $\mathrm{B}$.

\section{RESULTS}

\section{Isolation of bacteria}

All mealy bugs examined were found to support a population of acidophilic bacteria and yeasts, and filamentous fungal growth was rarely seen due to the incorporation of cycloheximide in the isolation medium. Bacterial colonies that resembled the growth of previous mealy-bug isolates, represented by strain SRI $1794^{\mathrm{T}}$, Gluconacetobacter liquefaciens or Gluconacetobacter diazotrophicus, on WL nutrient-agar plates (khaki-brown colonies producing large amounts of acid to change the colour of agar plates from aqua to yellow) were selected and isolated as pure cultures. New isolates included in this study are shown in Table 1 (IF numbers).

\section{Phenotypic relationships}

Twenty-four isolates were phenotypically characterized and the data were analysed by numerical analysis (Fig. 1). Strains SRI 244 and SRI 1957 clustered with the type strain of Gluconacetobacter liquefaciens (92 and $86 \%$ similarity, respectively) and strains SRI 1206, SRI 1212 and SRI 1990 clustered with the type strain of Gluconacetobacter diazotrophicus (92, 92 and 89\% similarity, respectively). Twelve strains, including three new isolates IF 2-6, IF 9700 and IF 9645, formed a highly related cluster independent of existing type strains included in the analysis. Strain SRI 1994 clustered with this group of isolates, but on a separate branch. All other unidentified isolates (except SRI 1321, which grouped with Gluconacetobacter xylinus) belonged to separate taxa and were not associated with the known species included.

Members of the major cluster of novel mealy-bug isolates were shown to be $100 \%$ similar on the basis of the tests conducted (Table 2). They are Gram-negative, ellipsoidal-to-rod-shaped cells, motile by peritrichous

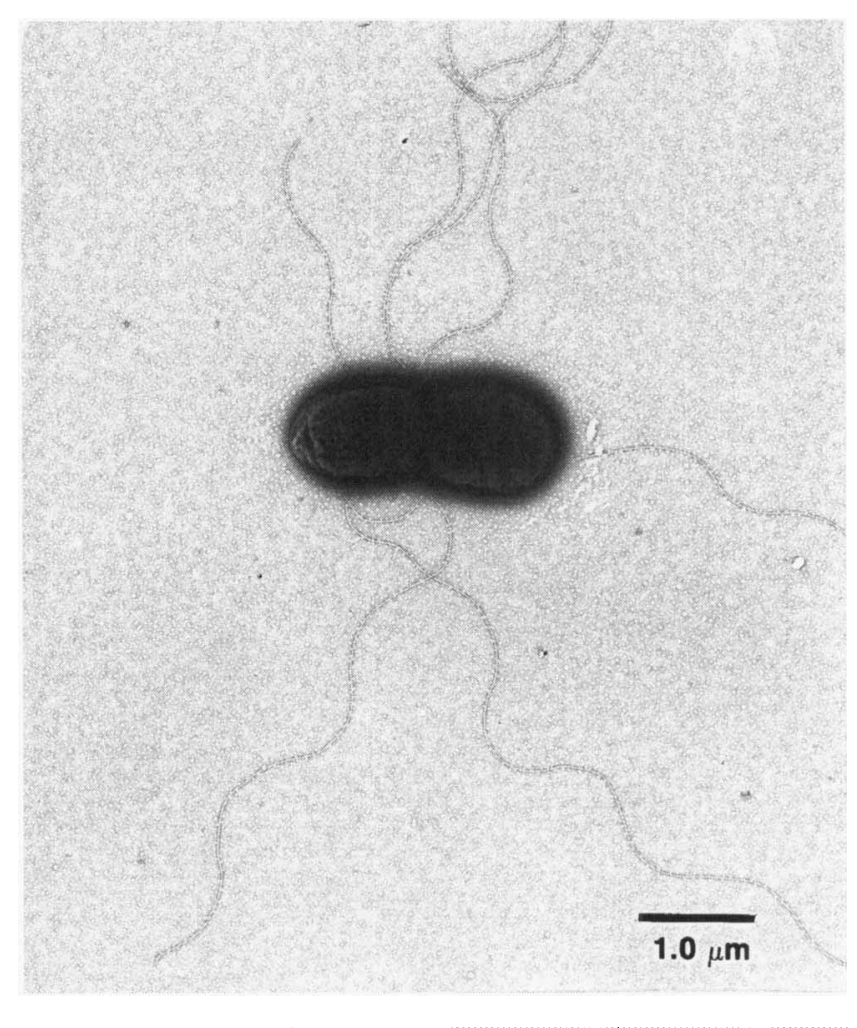

Fig. 2. Electron micrograph of strain SRI $1794^{\top}$, showing cellular morphology and peritrichous flagella.

flagella (Fig. 2) and produce a water-soluble brown pigment on GYC agar plates. Like all other reference strains tested, these novel isolates were capable of acid formation from glucose and the oxidation of ethanol. Members of the taxon were oxidase-negative, catalasepositive, unable to reduce nitrates, incapable of nitrogen fixation as determined by acetylene reduction and did not form hydrogen sulfide. Both sodium acetate and sodium lactate were oxidized. There was no growth in $6 \%$ ethanol, although bacteria did grow in $30 \%$ glucose. Growth occurred on glutamate agar, on mannitol agar and in the presence of $0.01 \%$ malachite green. There was no acid production from D-mannitol or sorbitol, but acid was formed from 1propanol. Organisms were capable of growth on $0 \cdot 1 \%$ ethanol and sodium acetate as sole carbon sources, but not on $0.1 \%$ methanol or dulcitol. No strains were able to utilize the amino acids L-asparagine, L-glycine, L-glutamine, L-threonine or L-tryptophan as sole nitrogen sources with D-mannitol as a carbon source. Bacteria of this taxon produced 2-keto, 5-keto and 2,5diketogluconic acids after $1-2 \mathrm{~d}$ growth.

\section{Fatty acid composition}

The predominant fatty acid found in all the acetic acid bacteria tested, both reference strains and mealy-bug isolates, was the straight-chain unsaturated $\mathrm{C}_{18: 1 \omega 7 \mathrm{c}}$ 
Description of Gluconacetobacter sacchari sp. nov.

Table 3. Cellular fatty acid composition of members of the novel taxon of mealy-bug isolates, type strains of Gluconacetobacter and Acetobacter and other bacteria isolated from mealy bugs

Percentages of total fatty acids are shown. Additional fatty acids found in smaller amounts in various isolates included: $0.69 \%$ 3-OH C $\mathrm{C}_{10: 0}$ in SRI 1313;0.83\% $\mathrm{C}_{12: 0}$ in SRI 1990; $0.44 \% \mathrm{C}_{17: 1 \text { (obc }}$ in SRI $1794^{\mathrm{T}} ; 1.05 \% \mathrm{C}_{17: 0}$ in G. liquefaciens LMG $1381^{\mathrm{T}}$; $0.53 \% \mathrm{C}_{17: 0}$ in SRI $1794^{\mathrm{T}} ; 0.28 \% 2-\mathrm{OH} \mathrm{C}_{16: 1}$ in SRI $1939 ; 1.25 \% \mathrm{C}_{18: 2 \omega 6,9 \mathrm{c}}$ in SRI 1957; and 0.79\% $\mathrm{C}_{19: 1 \omega 12 \mathrm{t}}$ in SRI 1939. - , Not detected.

\begin{tabular}{|c|c|c|c|c|c|c|c|c|c|c|c|c|}
\hline Strain & $\mathrm{C}_{14: 0}$ & $\begin{array}{c}\text { 2-OH } \\
\mathrm{C}_{\text {14:0 }}\end{array}$ & $\begin{array}{c}\text { 3-OH } \\
\mathrm{C}_{14: 0}\end{array}$ & $C_{16: 1 \omega 7 \mathrm{c}}$ & $C_{16: 0}$ & $\begin{array}{c}2-\mathrm{OH} \\
\mathrm{C}_{16: 0}\end{array}$ & $\begin{array}{c}3-\mathrm{OH} \\
\mathrm{C}_{16: 0}\end{array}$ & $\mathrm{C}_{18: 1 \omega 7 \mathrm{c}}$ & $\mathrm{C}_{18: 0}$ & $\mathrm{C}_{19: 0 \mathrm{cyclow} \text { se }}$ & $\begin{array}{c}2-\mathrm{OH} \\
\mathrm{C}_{18: 1}\end{array}$ & $C_{20: 3 \omega 6,9,12}$ \\
\hline \multicolumn{13}{|l|}{ A. aceti } \\
\hline ACM 17 & $2 \cdot 25$ & $6 \cdot 18$ & $1 \cdot 14$ & 0.70 & 11.55 & $2 \cdot 04$ & 1.61 & $70 \cdot 61$ & 1.68 & 0.75 & . & 1.48 \\
\hline SRI 1321 & $1 \cdot 18$ & $2 \cdot 89$ & $2 \cdot 05$ & - & $10 \cdot 52$ & $8 \cdot 80$ & $2 \cdot 47$ & $63 \cdot 30$ & $1 \cdot 35$ & - & $6 \cdot 32$ & $1 \cdot 11$ \\
\hline \multicolumn{13}{|c|}{ G. diazotrophicus } \\
\hline LMG $7603^{\mathrm{T}}$ & 6.08 & $4 \cdot 79$ & 0.98 & - & $7 \cdot 18$ & 6.84 & $2 \cdot 44$ & $66 \cdot 22$ & $1 \cdot 45$ & $2 \cdot 45$ & 1.58 & - \\
\hline SRI 1206 & $7 \cdot 43$ & $2 \cdot 24$ & 0.78 & - & $8 \cdot 32$ & 6.64 & $2 \cdot 00$ & $67 \cdot 76$ & $2 \cdot 04$ & $1 \cdot 24$ & $1 \cdot 54$ & - \\
\hline SRI 1212 & $6 \cdot 27$ & $3 \cdot 29$ & $0 \cdot 90$ & $0 \cdot 45$ & $7 \cdot 22$ & 6.69 & 1.92 & 68.05 & 1.55 & $1 \cdot 48$ & $1 \cdot 45$ & 0.72 \\
\hline SRI 1990 & $6 \cdot 14$ & $3 \cdot 41$ & - & - & $8 \cdot 33$ & 7.64 & $2 \cdot 13$ & $65 \cdot 73$ & 1.88 & - & - & - \\
\hline \multicolumn{13}{|l|}{ G. liquefaciens } \\
\hline LMG $1381^{\mathrm{T}}$ & $4 \cdot 43$ & $2 \cdot 97$ & 1.80 & - & 8.07 & 7.52 & $3 \cdot 35$ & $61 \cdot 49$ & $2 \cdot 81$ & 3.76 & $1 \cdot 43$ & 1.33 \\
\hline SRI 244 & $5 \cdot 80$ & $1 \cdot 41$ & 1.23 & - & $9 \cdot 35$ & 5.64 & $2 \cdot 35$ & $66 \cdot 14$ & $2 \cdot 62$ & 1.52 & $2 \cdot 90$ & 1.03 \\
\hline SRI 1957 & $5 \cdot 55$ & $2 \cdot 25$ & $1 \cdot 11$ & 1.03 & $8 \cdot 27$ & $6 \cdot 15$ & $2 \cdot 28$ & 67.62 & 1.57 & - & $2 \cdot 92$ & - \\
\hline SRI 1994 & $5 \cdot 57$ & 1.80 & $1 \cdot 23$ & - & $8 \cdot 50$ & $6 \cdot 41$ & $2 \cdot 24$ & 67.38 & 1.96 & $1 \cdot 16$ & $2 \cdot 94$ & 0.81 \\
\hline \multicolumn{13}{|c|}{ Novel mealy-bug taxon } \\
\hline SRI 1216 & $3 \cdot 12$ & $4 \cdot 53$ & 1.39 & - & $9 \cdot 32$ & $7 \cdot 31$ & $3 \cdot 15$ & $62 \cdot 14$ & $2 \cdot 26$ & $1 \cdot 10$ & $4 \cdot 62$ & $1 \cdot 07$ \\
\hline SRI 1230 & $2 \cdot 26$ & $4 \cdot 83$ & $1 \cdot 42$ & - & $9 \cdot 40$ & 7.94 & $2 \cdot 96$ & $63 \cdot 61$ & $1 \cdot 78$ & 1.08 & $3 \cdot 74$ & 0.99 \\
\hline SRI 1255 & $2 \cdot 19$ & $4 \cdot 29$ & $1 \cdot 46$ & - & $10 \cdot 37$ & 7.74 & $2 \cdot 74$ & $63 \cdot 40$ & 1.87 & 1.59 & $3 \cdot 16$ & $1 \cdot 20$ \\
\hline SRI $1794^{\mathrm{T}}$ & $2 \cdot 38$ & $5 \cdot 16$ & $1 \cdot 46$ & 0.68 & $11 \cdot 37$ & $8 \cdot 31$ & $2 \cdot 74$ & $60 \cdot 67$ & $1 \cdot 30$ & $1 \cdot 11$ & 2.77 & 1.08 \\
\hline SRI 1801 & $3 \cdot 35$ & 3.53 & $1 \cdot 27$ & - & $9 \cdot 62$ & 6.69 & $2 \cdot 78$ & $64 \cdot 13$ & $2 \cdot 12$ & $1 \cdot 16$ & $4 \cdot 45$ & 0.90 \\
\hline SRI 1853 & $3 \cdot 71$ & $5 \cdot 19$ & $1 \cdot 48$ & 0.66 & $15 \cdot 87$ & $9 \cdot 43$ & $3 \cdot 56$ & $49 \cdot 09$ & $5 \cdot 11$ & 0.89 & - & - \\
\hline SRI 1908 & $2 \cdot 87$ & $4 \cdot 41$ & 1.38 & - & $10 \cdot 48$ & $7 \cdot 27$ & $2 \cdot 46$ & $64 \cdot 29$ & 1.95 & 0.93 & 2.79 & $1 \cdot 17$ \\
\hline SRI 1939 & $1 \cdot 19$ & $4 \cdot 86$ & 1.57 & 0.66 & 10.59 & 5.74 & $2 \cdot 22$ & $63 \cdot 65$ & 2.63 & 0.61 & 4.06 & $1 \cdot 16$ \\
\hline SRI 1951 & $3 \cdot 81$ & 3.92 & 0.98 & - & $10 \cdot 48$ & 7.03 & $2 \cdot 93$ & $63 \cdot 86$ & $2 \cdot 03$ & - & $3 \cdot 82$ & $1 \cdot 14$ \\
\hline SRI 1953 & $3 \cdot 12$ & $4 \cdot 22$ & $1 \cdot 50$ & 0.86 & $9 \cdot 21$ & 7.96 & $3 \cdot 19$ & $61 \cdot 43$ & $1 \cdot 96$ & $1 \cdot 12$ & $4 \cdot 18$ & $1 \cdot 26$ \\
\hline IF $2-6$ & $2 \cdot 80$ & $4 \cdot 73$ & $1 \cdot 20$ & $0 \cdot 81$ & $10 \cdot 32$ & $7 \cdot 17$ & $2 \cdot 40$ & $64 \cdot 25$ & 1.79 & 1.55 & $2 \cdot 21$ & 0.78 \\
\hline IF 9645 & 3.03 & $4 \cdot 84$ & $1 \cdot 30$ & 0.90 & $9 \cdot 44$ & 7.76 & $2 \cdot 94$ & $63 \cdot 39$ & $1 \cdot 26$ & $1 \cdot 18$ & $3 \cdot 06$ & 0.91 \\
\hline IF 9700 & $2 \cdot 82$ & $5 \cdot 28$ & 1.51 & - & $9 \cdot 02$ & 8.88 & $2 \cdot 87$ & $63 \cdot 36$ & $1 \cdot 13$ & 0.88 & $3 \cdot 37$ & 0.88 \\
\hline \multicolumn{13}{|c|}{ Unidentified bacteria } \\
\hline SRI 1313 & 1.06 & $4 \cdot 37$ & $2 \cdot 58$ & - & 6.97 & $7 \cdot 22$ & $3 \cdot 09$ & $59 \cdot 29$ & $1 \cdot 12$ & - & $12 \cdot 15$ & 1.46 \\
\hline SRI 1793 & 0.87 & $4 \cdot 24$ & $2 \cdot 44$ & - & 7.89 & $7 \cdot 04$ & $2 \cdot 71$ & $61 \cdot 36$ & $1 \cdot 33$ & - & $10 \cdot 77$ & $1 \cdot 34$ \\
\hline SRI 1941 & - & 1.68 & $1 \cdot 48$ & - & $8 \cdot 83$ & $7 \cdot 81$ & $3 \cdot 48$ & $59 \cdot 03$ & $5 \cdot 06$ & - & 12.63 & - \\
\hline SRI 1995 & - & - & $1 \cdot 36$ & - & $9 \cdot 07$ & $7 \cdot 13$ & 3.58 & $69 \cdot 8$ & 0.97 & 1.34 & $5 \cdot 84$ & 0.89 \\
\hline
\end{tabular}

acid, which accounted for $49-71 \%$ of the fatty acid content (Table 3 ). Other fatty acids common to all members of the new taxon of bacteria were $\mathrm{C}_{14: 0}$ $(2 \cdot 2-3 \cdot 8 \%), C_{16: 0}(9 \cdot 0-15 \cdot 9 \%), C_{18: 0}(1 \cdot 1-5 \cdot 1 \%), 2-$ OH C $14: 0(3 \cdot 5-5 \cdot 3 \%), 2-\mathrm{OH} \mathrm{C} \mathrm{C}_{16: 0}(6 \cdot 7-9 \cdot 4 \%), 3-\mathrm{OH}$ $\mathrm{C}_{14: 0}(1 \cdot 0-1 \cdot 5 \%)$ and $3-\mathrm{OH} \mathrm{C} \mathrm{C}_{16: 0}(2 \cdot 4-3 \cdot 6 \%)$. The fatty acid compositions of Acetobacter aceti and Gluconacetobacter liquefaciens are in agreement with earlier studies of Yamada et al. (1981) and Urakami et al. (1989). Principal-component analysis of fatty acid profiles grouped all members of the novel taxon except for SRI 1853 together and separate from Gluconacetobacter liquefaciens and Gluconacetobacter diazotrophicus.

\section{5 rRNA gene sequence analysis}

Near-complete 16S rRNA gene sequences (1341-1420 nucleotides) were determined for 23 strains of acetic acid bacteria, including 10 strains of the novel taxon. Fig. 3 shows a dendrogram constructed from evolutionary distances using the neighbour-joining method, based on 1241 nucleotide positions (ambiguous nucleotides omitted). Bootstrap values supported the topology of the tree. The parsimony tree (not shown) reflected the topology of the neighbour-joining tree. Phylogenetically, the acetic acid bacteria form two major divisions, one containing all species of the genus Gluconacetobacter and the second containing 


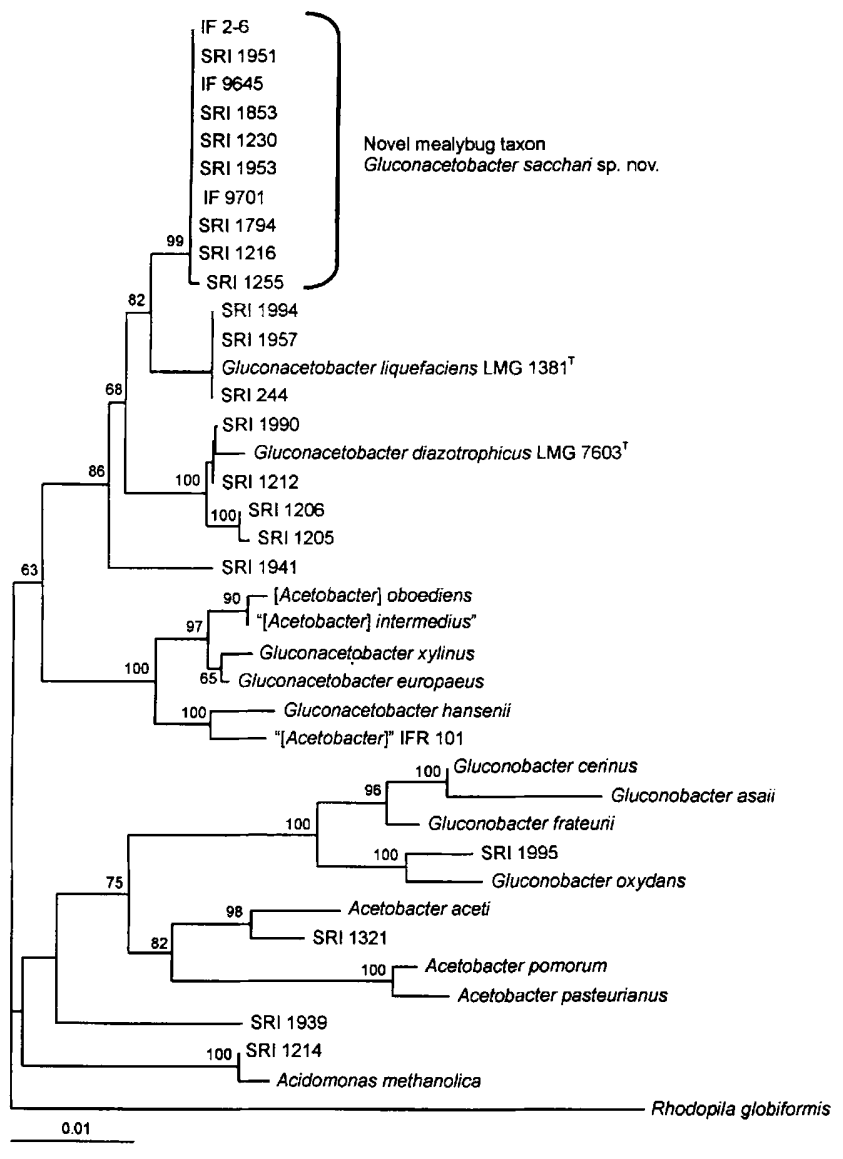

Fig. 3. Neighbour-joining tree depicting the phylogenetic relationships of mealy-bug isolates among the Acetobacteraceae determined from 16S rRNA gene sequence similarities. The scale bar represents 1 nucleotide substitution per 100 nucleotides.

separate lineages for the genera Gluconobacter, Acetobacter and Acidomonas. Two subdivisions were evident within the genus Gluconacetobacter, the first including members of the novel mealy-bug taxon, Gluconacetobacter diazotrophicus and Gluconacetobacter liquefaciens and the other containing Gluconacetobacter europaeus, Gluconacetobacter hansenii, Gluconacetobacter xylinus and some newly sequenced and misidentified Acetobacter species, [Acetobacter] oboediens and '[Acetobacter] intermedius', which should be reassigned to the genus Gluconacetobacter. Strains of the new mealy-bug-isolate taxon clustered together and separately from other species of the genus Gluconacetobacter. All sequenced members of the taxon were found to be almost identical, with strains sharing $99 \cdot 5-100 \%$ sequence similarity. The nearest relative of this group is Gluconacetobacter liquefaciens, which, although seemingly a distinct phylotype, shares $98.8-99 \cdot 3 \%$ sequence similarity with members of the mealy-bug taxon. There is $97.9-98.5 \%$ sequence similarity between members of the mealy-bug taxon and Gluconacetobacter diazotrophicus, and progressively lower similarity to the other species of Gluconaceto- bacter; Gluconacetobacter xylinus (97\%), Gluconacetobacter europaeus $(97.2 \%)$ and Gluconacetobacter hansenii $(96.9 \%)$. The closest relative of the Acetobacteraceae family was found to be Rhodopila globiformis. Unique nucleotide positions in the $16 \mathrm{~S}$ rRNA gene were found in isolates of the novel mealybug taxon and in no other members of the genus Gluconacetobacter. The $\mathrm{G}$ at position 648 (Escherichia coli numbering) was characteristic for members of the novel taxon, and the bases $\mathrm{U}, \mathrm{U}$ and $\mathrm{A}$ at positions 264, 265 and 647 were characteristic for members of the novel taxon and found in no other members of the genus Gluconacetobacter, with the exception of strains SRI 1941 (U at position 265, A at position 647) and SRI 1939 (U at position 264). These strains appear to be the first representatives of undescribed species of Gluconacetobacter (SRI 1941) and Acetobacter (SRI 1939).

\section{DNA characterization}

The base composition ranges of the novel taxon of mealy-bug isolates and their nearest phylogenetic relatives are shown in Table 2. All members of the novel taxon tested were found to have $\mathrm{G}+\mathrm{C}$ contents ranging from $62 \cdot 1$ to $67.3 \mathrm{~mol} \%$. DNA base compositions of the type strains determined in this study were found to resemble published values closely (Gluconacetobacter diazotrophicus, $62 \pm 0.4 \mathrm{~mol} \%$, Gluconacetobacter liquefaciens, $62 \cdot 1 \pm 0.3 \mathrm{~mol} \%$, and Acetobacter aceti, $60 \cdot 7 \pm 0 \cdot 1 \mathrm{~mol} \%$ ) (De Ley et al., 1984; Swings et al., 1992). Values for isolates related to the type strains were similar to the $\mathrm{G}+\mathrm{C}$ contents obtained for the reference strains of Gluconacetobacter diazotrophicus (SRI 1205, 66 $\pm 0.2 \mathrm{~mol} \%$, SRI 1212, $66 \pm 0.1 \mathrm{~mol} \%$, and SRI $1990,66.3 \pm 0.4 \mathrm{~mol} \%$ ) and Gluconacetobacter liquefaciens (SRI 244, $66 \cdot 8 \pm 0 \cdot 4 \mathrm{~mol} \%$, SRI $1957,65 \pm 0 \cdot 2 \mathrm{~mol} \%$, and SRI $1994,65 \cdot 1 \pm 0 \cdot 1 \mathrm{~mol} \%$ ).

The levels of DNA-DNA reassociation among members of the acetic acid bacteria studied (Table 4) indicate that the novel mealy-bug isolates belong to a new species. Hybridization values of $78-100 \%$ were obtained for all reassociation experiments conducted between various strains belonging to the taxon. In contrast, there was only $46 \%$ relatedness between the DNA of the novel taxon reference strain, SRI $1794^{\mathrm{T}}$, and Gluconacetobacter liquefaciens and $39 \%$ relatedness with Gluconacetobacter diazotrophicus, the two nearest phylogenetic relatives determined by $16 \mathrm{~S}$ rDNA sequence similarity. There was $52 \%$ relatedness between another member of the novel taxon, IF 9645, and Gluconacetobacter liquefaciens. Strains SRI 244, SRI 1957 and SRI 1994 showed 69-72\% relatedness to the type strain of Gluconacetobacter liquefaciens and $85-100 \%$ relatedness among each other, and strains SRI 1205, SRI 1212 and SRI 1990 showed 85-89\% relatedness to the type strain of Gluconacetobacter diazotrophicus. 
Table 4. DNA-DNA relatedness among members of the novel taxon of mealy-bug isolates, Gluconacetobacter and Acetobacter strains and other bacteria isolated from mealy bugs

Percentage DNA binding is shown.

\begin{tabular}{|c|c|c|c|c|c|c|c|c|c|c|}
\hline Strain & 1 & 3 & 6 & 7 & 8 & 9 & 10 & 12 & 13 & 14 \\
\hline 1. SRI $1794^{\mathrm{T}}$ & 100 & & & & & & & & & \\
\hline 2. SRI 1216 & 78 & & 82 & & & & & & & \\
\hline 3. SRI 1230 & 100 & & & & & & & & & \\
\hline 4. SRI 1853 & 83 & 83 & & & & & & & & \\
\hline 5. SRI 1951 & 86 & & & 90 & & & & & & \\
\hline 6. IF 2-6 & 88 & & & & & & & & & \\
\hline 7. IF 9645 & 97 & & & & 52 & & & 43 & & \\
\hline 8. G. liquefaciens $\mathrm{LMG} 1381^{\mathrm{T}}$ & 46 & & & & & & & & & \\
\hline 9. SRI 244 & 38 & & & & 69 & & & 38 & & \\
\hline 10. SRI 1957 & & & & & 71 & 85 & & & & \\
\hline 11. SRI 1994 & & & & & 72 & 92 & 100 & & & \\
\hline 12. G. diazotrophicus LMG $7603^{\mathrm{T}}$ & 39 & & & & 38 & & & & & \\
\hline 13. SRI 1205 & & & & & & & & 87 & & \\
\hline 14. SRI 1212 & & & & & & & & 89 & 90 & \\
\hline 15. SRI 1990 & & & & & & & & 85 & 88 & 96 \\
\hline 16. A. aceti ACM 17 & 23 & & & & 18 & & & 30 & & \\
\hline 17. SRI 1939 & 29 & & & & 28 & & & 30 & & \\
\hline 18. SRI 1941 & 34 & & & & 23 & & & 37 & & \\
\hline
\end{tabular}

\section{DISCUSSION}

A polyphasic study of acetic acid bacteria isolated from the sugar cane leaf sheath and from the pink sugar-cane mealy bug has revealed a new species of the genus Gluconacetobacter, for which we propose the name Gluconacetobacter sacchari sp. nov., and has also shown the presence of its nearest phylogenetic relatives, Gluconacetobacter liquefaciens and Gluconacetobacter diazotrophicus, in this environment. The 16S rDNA sequences of all strains of the new taxon were very similar ( $>99.5 \%$ sequence similarity), despite having been isolated over a 17-year period from various geographical regions.

The phylogenetic tree generated in this study is mainly in agreement with the 5S rRNA gene sequence study by Bulygina et al. (1992) of several Acetobacter and Gluconobacter strains and is in accordance with the 16S rRNA gene study of Sievers et al. (1994a), showing essentially two main lineages. A recent study of partial $16 \mathrm{~S}$ rRNA gene sequences and ubiquinone content led to the elevation of the Acetobacter subgenus Gluconoacetobacter (Yamada \& Kondo, 1984) to the generic level (Yamada et al., 1997). The number of base differences between Acetobacter aceti and Gluconacetobacter liquefaciens was found to be greater than the number between Acetobacter aceti and Gluconobacter oxydans. This indicated that the phylogenetic distance between members of the subgenera Acetobacter and Gluconacetobacter of the genus Acetobacter is greater than that between members of the subgenus Acetobacter of the genus Acetobacter and the genus Gluconobacter. Our alignment of the almost complete 16S rDNA sequences from the same strains of acetic acid bacteria indicated a nearly identical phylogeny and clearly confirms the findings of Yamada et al. (1997). Ubiquinone content in these organisms was also found to differ. While Acidomonas and members of Gluconacetobacter and Gluconobacter were equipped with the Q10 ubiquinone, members of the genus Acetobacter were equipped with the Q9 ubiquinone. The presence of Q10 as ubiquinone in the mealy-bug isolates strongly supports the inclusion of the new species in the genus Gluconacetobacter (Yamada et al., 1997) with the organisms it shares the greatest similarity to on the basis of $16 \mathrm{~S}$ rRNA gene sequence information. There was only one position in the $16 \mathrm{~S}$ rRNA gene (G at $648, E$. coli numbering) that was unique within the genus Gluconacetobacter to members of the novel taxon of mealy-bug isolates, and three positions (U, U and A, at positions 264,265 and $647, E$. coli numbering) that were unique within the genus Gluconacetobacter to members of the novel taxon of mealy-bug isolates with the exception of the unidentified strains SRI 1941 (U at position 265, A at position 647) and SRI 1939 (U at position 264).

DNA-DNA hybridization is acknowledged to be the superior method for the elucidation of relationships between closely related taxa at the species level and the newer technique of gene sequence analysis has been found most often to confirm DNA reassociation results (Fox et al., 1992; Stackebrandt \& Goebel, 1994). Bacteria demonstrating $>70 \%$ DNA hom- 
ology are regarded as belonging to the same species and would be expected to exhibit $97.5 \%$ or greater $16 \mathrm{~S}$ rRNA gene sequence similarity (Stackebrandt \& Goebel, 1994). All mealy-bug isolates belonging to the novel taxon were found to have a high level of DNA homology with each other $(>78 \%)$ and low levels of homology with the most closely related species of the genus Gluconacetobacter (determined by rRNA phylogeny). This is evidence for the designation of a new species of Gluconacetobacter.

The $\mathrm{G}+\mathrm{C}$ content determinations for the strains of the new species were found to be slightly higher than the $51-65 \mathrm{~mol} \%$ range originally described for the genus (De Ley et al., 1984; Yamada \& Kondo, 1984). Most of the strains tested were found to have a $\mathrm{G}+\mathrm{C}$ content between 65.1 and $67.3 \mathrm{~mol} \%$, although one strain, SRI 1853, had a G+C content of $62 \cdot 1 \mathrm{~mol} \%$. This strain also had a different fatty acid profile from the other strains of the species, but did not differ phenotypically, nor in the 16S rRNA gene sequence. Its inclusion in the species is further supported by high DNA reassociation levels with other members of the new species. A number of different methods have been used for the determination of $\mathrm{G}+\mathrm{C}$ content and results have been found to differ depending on the method used (Tamaoka \& Komagata, 1984; Fahmy et al., 1985). For this reason, the fact that the $\mathrm{G}+\mathrm{C}$ contents obtained for isolates of the species were slightly higher than those recorded previously for the Acetobacteraceae is not considered to be a barrier to their inclusion in the family.

All strains of the new species were identical by phenotypic characterization and shared similar chemotaxonomic features. No exclusive phenotypic character differentiated the new species from all other related bacteria; however, tests such as growth in the presence of $0.01 \%$ malachite green, the inability to fix nitrogen, growth on $30 \%$ glucose (a characteristic previously specific for Gluconacetobacter diazotrophicus, another bacterium isolated from sugar cane) and the inability to grow on various L-amino acids in the presence of D-mannitol as carbon source allowed the differentiation of the species from other species of the genera Gluconacetobacter and Acetobacter. Numerical analysis of the phenotypic characteristics placed the mealy-bug isolates in a separate group. The results obtained for the various reference strains included in this study mostly supported the results of previous researchers (De Ley et al., 1984; Cavalcante \& Döbereiner, 1988), although there were a few discrepancies. We found that Gluconacetobacter diazotrophicus was able to grow with L-glycine and Lglutamine in the presence of D-mannitol as carbon source. We also found that Gluconacetobacter xylinus ACM 19, a non-type strain, was incapable of glycerol ketogenesis and that Acetobacter aceti ACM 17, also a non-type strain, was capable of nitrate reduction. A high level of sensitivity was obtained when detecting ketogluconic acids formed from glucose, and low levels of 5-ketogluconic acid were detected in all bacteria tested. This was not expected for Acetobacter pasteurianus or Gluconacetobacter diazotrophicus. Ketogluconic acids were formed by Gluconacetobacter diazotrophicus, Gluconacetobacter liquefaciens and members of the new species after $24 \mathrm{~h}$ growth, but only after $7 \mathrm{~d}$ growth for Gluconacetobacter xylinus, Acetobacter pasteurianus and Acetobacter aceti. Yamada et al. (1997) reported that growth on mannitol agar can be used to differentiate between the genera Acetobacter, Gluconobacter, Gluconoacetobacter and Acidomonas. In our study, all Acetobacter and Gluconacetobacter species grew on mannitol. None of the species tested were capable of acid formation from mannitol. Members of the novel taxon exhibit a combination of properties that have not been described previously for any member species of the Acetobacteraceae. However, it is clear that the phenotypic relationships revealed in the phenogram generated by numerical analysis do not reflect the phylogenetic relationships determined by $16 \mathrm{~S}$ rRNA sequence analysis. The novel taxon falls in the same lineage as Acetobacter aceti, Gluconacetobacter xylinus and Acetobacter pasteurianus and, in the 16S rRNA gene phylogenetic tree, the novel mealybug isolates clustered closer to Gluconacetobacter diazotrophicus and Gluconacetobacter liquefaciens and more distantly to the Gluconacetobacter xylinus group and the Acetobacter and Gluconobacter groups. Strain SRI $1794^{\mathrm{T}}$, representative of the species, has higher phenotypic similarity to Acetobacter pasteurianus $(81 \%)$ than to Gluconacetobacter diazotrophicus $(79 \%)$ or Gluconacetobacter liquefaciens $(76 \%)$. These conflicting relationships indicate the inability of phenotypic characters to determine phylogenetic relationships amongst members of the Acetobacteraceae, which resulted in the need for its recent taxonomic revision (Yamada et al., 1997).

Gillis et al. (1989) published a description of a new nitrogen-fixing acetic acid bacterium, Acetobacter diazotrophicus. This paper included a paragraph mentioning that sugar cane isolates from Australia belong to the species Acetobacter diazotrophicus on the basis of their growth characteristics, protein gel electropherograms and nitrogen-fixing ability. The strains included in their study were the SRI strains 244, 1205 , 1206, 1212, 1214 and 1216 (M. Gillis, personal communication). Only three of these strains (SRI 1205, SRI 1206 and SRI 1212) were found in our study to group with Gluconacetobacter diazotrophicus on the basis of 16S rRNA gene sequence analysis, phenotypic tests (including acetylene reduction as a test for nitrogen fixation) and DNA-DNA hybridization. Of the other strains, we found strain SRI 1216 to belong to the new species according to 16S rRNA gene sequence similarity and the absence of acetylene reduction activity, strain SRI 244 to belong to Gluconacetobacter liquefaciens and strain SRI 1214 to group most closely with Acidomonas methanolica, a result also found by M. Gillis (personal communication).

Results of fatty acid analyses have been found most 
often to support 16S rRNA gene phylogeny (Klatte et al., 1994; Kämpfer et al., 1997). In our study, the results appear also to be consistent with phylogenetic data, although not all Acetohacter and Gluconacetobacter reference species were included in the analysis. The fatty acid compositions of bacteria tested were in agreement with the results obtained by Yamada et al. (1981) for Acetobacter and Gluconacetobacter, where $\mathrm{C}_{18: 1 \omega 7 \mathrm{e}}$ was the major fatty acid constituent and $\mathrm{C}_{16: 0}$ and 2-OH $\mathrm{C}_{16: 0}$ were also present in significant amounts. The fatty acid $\mathrm{C}_{18: 1 \omega 7 \mathrm{zc}}$ comprised $60-64 \%$ of the total fatty acid content of the mealy-bug isolates, except for SRI 1853, in which $\mathrm{C}_{18: 1 \omega 7}$ represented only $49 \%$ of the total fatty acid composition. The fatty acid $2-\mathrm{OH} \mathrm{C}_{18: 1}$ was missing from the profile of SRI 1853 , a fatty acid present in all other members in small amounts $(2 \cdot 2-4 \cdot 6 \%)$. In contrast, SRI 1853 had raised levels of $\mathrm{C}_{16: 0}$ and $\mathrm{C}_{18: 0}$. These results and the lower $\mathrm{G}+\mathrm{C}$ content obtained for SRI 1853 indicate the unique phenotypic properties of this strain. Although there was no single fatty acid found in significant levels in the new species and absent in all other organisms, bacteria of the new species (except SRI 1853) did cluster together and separately from other strains by principal-component analysis of fatty acid data. Microbial fatty acid composition of lipids is highly dependent on environmental conditions and standardization in the entire culturing and extraction procedure is critical for reproducibility (Mukwaya \& Welch, 1989). The small amount of variation in fatty acid profiles between the different mealy-bug isolates is therefore not significant.

\section{Description of Gluconacetobacter sacchari sp. nov.}

Gluconacetobacter sacchari (sacch.ar'i. M.L. gen. n. sacchari, pertaining to the genus Saccharum, sugar cane, from which the organism was isolated).

Cells are ellipsoidal to rod-shaped, approximately $1.3-2.2 \times 0.7-0.9 \mu \mathrm{m}$ in size and occur singly, in pairs or in short chains. Cells are motile by peritrichous flagella. Resting stages are not formed. Strictly aerobic. Gram-negative, oxidase-negative and catalase-positive. Produce brown water-soluble pigments on GYC medium and khaki-brown colonies on WL nutrient agar plates. High levels of acid are produced on both these media. Optimum temperature for growth is around $28-30{ }^{\circ} \mathrm{C}$. Nitrates are not reduced to nitrite, hydrogen sulfide is not formed and microaerophilic nitrogen fixation as determined by acetylene reduction is negative. Acid is formed from glucose and ethanol is oxidized. Both sodium acetate and sodium lactate are oxidized. Isolates do not grow in $6 \%$ ethanol but do grow in $30 \%$ glucose. Isolates grow on glutamate agar, on mannitol agar and in the presence of $0.01 \%$ malachite green. Acid is produced from propanol, but not from D-mannitol or sorbitol. Isolates grow using $0.1 \%$ ethanol and sodium acetate as sole carbon sources, but not $0 \cdot 1 \%$ methanol or dulcitol. Members of the species do not grow on the amino acids L- asparagine, L-glycine, L-glutamine, L-threonine or Ltryptophan with D-mannitol as the carbon source. Produce 2-keto, 5-keto and 2,5-diketogluconic acids. $\mathrm{C}_{18: 1 \omega 7 \mathrm{c}}$ is the major cellular fatty acid, with $2-\mathrm{OH}$ $\mathrm{C}_{16: 0}$ and $\mathrm{C}_{16: 0}$ present in smaller but significant amounts. The ubiquinone type is Q10. The mean $\mathrm{G}+\mathrm{C}$ content (as determined by HPLC) ranges from 62 to $67 \mathrm{~mol} \%$. The bacteria were isolated from the leaf sheath of sugar cane and from the pink sugar-cane mealy bug, found living in the leaf sheath of sugar cane in Queensland, Australia. The type strain is SRI $1794^{\mathrm{T}}$ $\left(=\mathrm{DSM} 12717^{\mathrm{T}}\right)$, which has a $\mathrm{G}+\mathrm{C}$ content of $65 \mathrm{~mol} \%$ and has all the characteristics given above for the species.

\section{ACKNOWLEDGEMENTS}

This work was supported by a research grant from the Sugar Research and Development Corporation. We are indebted to the Sugar Research Institute for use of bacterial isolates, to the Bureau of Sugar Experiment Stations (BSES) throughout Queensland for their assistance with mealy bug collection, to Rick Webb at the Department of Microbiology, University of Queensland, for his help with electron microscopy, to Niall Masel (BSES) for his work in ketogluconic acid detection and to Professor R. Kroppenstedt for allowing chemotaxonomic work to be conducted in his laboratory at the DSMZ and for his expert advice. We thank Jutta Burghardt at the DSMZ for technical assistance with DNA-DNA hybridization and Birgit Frerichs and Gabi Potter at the DSMZ for technical assistance with fatty acid analyses.

\section{REFERENCES}

Asai, T., lizuka, H. \& Komagata, K. (1964). The flagellation and taxonomy of genera Gluconobacter and Acetobacter with reference to the existence of intermediate strains. $J$ Gen Appl Microbiol 10, 95-126.

Ashbolt, N. J. \& Inkerman, P. A. (1990). Acetic acid bacterial biota of the pink sugarcane mealybug, Saccharococcus sacchari, and its environs. Appl Environ Microbiol 56, 707-712.

Blake, J. D., Clarke, M. L. \& Richards, G. N. (1984). Determination of D-gluconic, 5-keto-D-gluconic, 2-keto-D-gluconic and 2,5diketo-D-gluconic acids by high-performance liquid chromatography. J Chromat 312, 211-219.

Bulygina, E. S., Gulikova, O. M., Dikanskaya, E. M., Netrusov, A. I., Tourova, T. P. \& Chumakov, K. M. (1992). Taxonomic studies of the genera Acidomonas, Acetobacter and Gluconobacter by $5 \mathrm{~S}$ ribosomal RNA sequencing. J Gen Microbiol 138, 2283-2286.

Carr, J. G. (1968). Method for identifying acetic acid bacteria. In Identification Methods for Microbiologists, pp. 1-8. Edited by B. M. Gibbs \& D. A. Shapton. London: Academic Press.

Cashion, P., Holder-Franklin, M. A., McCully, J. \& Franklin, M. (1977). A rapid method for the base ratio determination of bacterial DNA. Anal Biochem 81, 461-466.

Cavalcante, V. A. \& Döbereiner, J. (1988). A new acid-tolerant nitrogen-fixing bacterium associated with sugarcane. Plant Soil 108, 23-31.

De Ley, J., Cattoir, H. \& Reynaerts, A. (1970). The quantitative measurement of DNA hybridization from renaturation rates. Eur J Biochem 12, 133-142. 
De Ley, J., Swings, J. \& Gosselé, F. (1984). Genus I. Acetobacter Beijerinck 1898, 215 $5^{\mathrm{AL}}$. In Bergey's Manual of Systematic Bacteriology, vol. 1, pp. 268-274. Edited by N. R. Krieg \& J. G. Holt. Baltimore: Williams \& Wilkins.

Entani, E., Ohmori, S., Masai, H. \& Suzuki, K.-I. (1985). Acetobacter polyoxogenes sp. nov., a new species of an acetic acid bacterium useful for producing vinegar with high acidity. J Gen Appl Microbiol 31, 475-490.

Escara, J. F. \& Hutton, J. R. (1980). Thermal stability and renaturation of DNA in dimethyl sulfoxide solutions: acceleration of the renaturation rate. Biopolymers 19, 1315-1327.

Fahmy, F., Flossdorf, J. \& Claus, D. (1985). The DNA base composition of the type strains of the genus Bacillus. Syst Appl Microbiol 6, 60-65.

Felsenstein, J. (1993). PHYLIP (Phylogeny Inference Package) version $3.5 \mathrm{c}$. Distributed by author. Department of Genetics, University of Washington, Seattle, WA, USA.

Fox, G. E., Wisotzkey, J. D. \& Jurtshuk, P., Jr (1992). How close is close: 16S rRNA sequence identity may not be sufficient to guarantee species identity. Int J Syst Bacteriol 42, 166-170.

Frateur, J. (1950). Essai sur la systematique des Acetobacters. Cellule 53, 287-392.

Gillis, M. \& De Ley, J. (1980). Intra- and intergeneric similarities of the ribosomal ribonucleic acid cistrons of Acetobacter and Gluconobacter. Int J Syst Bacteriol 30, 7-27.

Gillis, M., Kersters, K., Hoste, B., Janssens, D., Kroppenstedt, R. M., Stephan, M. P., Teixeira, K. R. S., Döbereiner, J. \& De Ley, J. (1989). Acetobacter diazotrophicus sp. nov., a nitrogen-fixing acetic acid bacterium associated with sugarcane. Int $J$ Syst Bacteriol 39, 361-364.

Gosselé, F., Swings, J., Kersters, K. \& De Ley, J. (1983). Numerical analysis of phenotypic features and protein gel electropherograms of Gluconobacter Asai 1935 emend. mut. char. Asai, Iizuka, and Komagata 1964. Int J Syst Bacteriol 33, 65-81.

Hippe, H., Hagenauer, A. \& Kroppenstedt, R. M. (1997). Menadione requirement for sulphate-reduction in Desulfotomaculum aeronauticum, and emended species description. Syst Appl Microbiol 20, 554-558.

Huss, V. A. R., Festl, H. \& Schleifer, K. H. (1983). Studies on the spectrophotometric determination of DNA hybridisation from renaturation rates. Syst Appl Microbiol 4, 184-192.

Inkerman, P. A., Ashbolt, N. J., Carver, M. \& Williams, D. J. (1986). Observations on the pink sugarcane mealybug, Saccharicoccus sacchari (Cockerell), in Australia (Homoptera: Pseudococcidae). In Proceedings of the 19th Congress of the International Society for Sugarcane Technology, Jakarta, Indonesia, vol. 1, pp. 612-618.

Jahnke, K.-D. (1992). BASIC computer program for evaluation of spectroscopic DNA renaturation data from GILFORD SYSTEM 2600 spectrophotometer on a PC/XT/AT type personal computer. $J$ Microbiol Methods 15, 61-73.

Jukes, T. H. \& Cantor, C.R. (1969). Evolution of protein molecules. In Mammalian Protein Metabolism, pp. 21-132. Edited by H. N. Munro. New York: Academic Press.

Kämpfer, P., Meyer, S. \& Müller, H. E. (1997). Characterisation of Buttiauxella and Kluyvera species by analysis of whole cell fatty acid patterns. Syst Appl Microbiol 20, 566-571.

Klatte, S., Jahnke, K.-D., Kroppenstedt, R. M., Rainey, F. \& Stackebrandt, E. (1994). Rhodococcus luteus is a later subjective synonym of Rhodococcus fascians. Int J Syst Bacteriol 44, $627-630$.

Kovacs, N. (1956). Identification of Pseudomonas pyocyanea by the oxidase reaction. Nature 178, 703.

Lane, D. J. (1991). 16S/23S rRNA sequencing. In Nucleic Acid Techniques in Bacterial Systematics, pp. 115-147. Edited by E. Stackebrandt \& M. Goodfellow. Chichester: Wiley.

Li, R. P. \& Macrae, I. C. (1991). Specific association of diazotrophic Acetobacters with sugarcane. Soil Biol Biochem 23, 999-1002.

Maidak, B. L., Olsen, G. J., Larsen, N., Overbeek, R., McCaughey, W. J. \& Woese, C. R. (1997). The RDP (Ribosomal Database Project). Nucleic Acids Res 25, 109-111.

Mesbah, M., Premachandran, U. \& Whitman, W. B. (1989). Precise measurement of the $\mathrm{G}+\mathrm{C}$ content of deoxyribonucleic acid by high-performance liquid chromatography. Int $J$ Syst Bacteriol 39, 159-167.

Micales, B. K., Johnson, J. L. \& Claus, G. W. (1985). Deoxyribonucleic acid homologies among organisms in the genus Gluconobacter. Int J Syst Bacteriol 35, 79-85.

Mukwaya, G. M. \& Welch, D. F. (1989). Subgrouping of Pseudomonas cepacia by cellular fatty acid composition. J Clin Microbiol 27, 2640-2646.

Persoon, C. H. (1822). Mycologia Europaea, Section 1, p. 96.

Saitou, N. \& Nei, M. (1987). The neighbor-joining method: a new method for reconstructing phylogenetic trees. Mol Biol Evol 4, 406-425.

Sievers, M. \& Teuber, M. (1995). The microbiology and taxonomy of Acetobacter europaeus in commercial vinegar production. $J$ Appl Bacteriol (Symposium Suppl.) 79, 84S-95S.

Sievers, M., Sellmer, S. \& Teuber, M. (1992). Acetobacter europaeus sp. nov., a main component of industrial vinegar fermenters in central Europe. Syst Appl Microbiol 15, 386-392.

Sievers, M., Ludwig, W. \& Teuber, M. (1994a). Phylogenetic positioning of Acetobacter, Gluconobacter, Rhodopila and Acidiphilium species as a branch of acidophilic bacteria in the $\alpha$ subclass of Proteobacteria based on 16S ribosomal DNA sequences. Syst Appl Microbiol 17, 189-196.

Sievers, M., Ludwig, W. \& Teuber, M. (1994b). Revival of the species Acetobacter methanolicus (ex Uhlig et al., 1986) nom. rev. Syst Appl Microbiol 17, 352-354.

Skerman, V. B. D. (1967). A Guide to the Identification of the Genera of Bacteria, 2nd edn. Baltimore: Williams \& Wilkins.

Sokollek, S. J., Hertel, C. \& Hammes, W. P. (1998). Description of Acetobacter oboediens sp. nov. and Acetobacter pomorum sp. nov., two new species isolated from industrial vinegar fermentations. Int J Syst Bacteriol 48, 935-940.

Stackebrandt, E. \& Charfreitag, O. (1990). Partial 16S rRNA primary structure of five Actinomyces species: phylogenetic implications and development of an Actinomyces israeliispecific oligonucleotide probe. J Gen Microbiol 136, 37-43.

Stackebrandt, E. \& Goebel, B. M. (1994). Taxonomic note: a place for DNA-DNA reassociation and 16S rRNA sequence analysis in the present species definition in bacteriology. Int $J$ Syst Bacteriol 44, 846-849.

Swings, J. (1992). The Genera Acetobacter and Gluconobacter. In The Prokaryotes, pp. 2268-2286. Edited by A. Balows, H. G. Trüper, M. Dworkin, W. Harder \& K.-H. Schleifer. New York: Springer.

Swings, J., Gillis, M. \& Kersters, K. (1992). Phenotypic identification of acetic acid bacteria. In Identification Methods in 
Applied and Environmental Microbiology, pp. 103-110. Edited by R. G. Board, D. Jones \& F. A. Skinner. Oxford: Blackwell Scientific.

Tamaoka, J. \& Komagata, K. (1984). Determination of DNA base composition by reversed-phase high-performance liquid chromatography. FEMS Microbiol Lett 25, 125-128.

Uhlig, H., Karbaum, K. \& Steudel, A. (1986). Acetobacter methanolicus sp. nov., an acidophilic facultatively methylotrophic bacterium. Int J Syst Bacteriol 36, 317-322.

Urakami, T., Tamaoka, J., Suzuki, K.-i. \& Komagata, K. (1989). Acidomonas gen. nov., incorporating Acetobacter methanolicus as Acidomonas methanolica comb. nov. Int J Syst Bacteriol 39, $50-55$.

Yamada, Y. \& Kondo, K. (1984). Gluconacetobacter, a new subgenus comprising the acetate-oxidising acetic acid bacteria with ubiquinone-10 in the genus Acetobacter. J Gen Appl Microbiol 30, 297-303.

Yamada, Y., Nunoda, M., Ishikawa, T. \& Tahara, Y. (1981). The cellular fatty acid composition in acetic acid bacteria. $J$ Gen Appl Microbiol 27, 405-417.

Yamada, Y., Hoshino, K.-I. \& Ishikawa, T. (1997). The phylogeny of acetic acid bacteria based on the partial sequences of $16 \mathrm{~S}$ ribosomal RNA: the elevation of the subgenus Gluconoacetobacter to the generic level. Biosci Biotechnol Biochem 61, 1244-1251.

Yamada, Y., Hoshino, K.-I. \& Ishikawa, T. (1998). Gluconacetobacter nom. corrig. (Gluconoacetobacter [sic]). In Validation of Publication of New Names and New Combinations Previously Effectively Published Outside the IJSB, List no. 64. Int J Syst Bacteriol 48, 327-328. 